\title{
REGIONAL ANALGESIA MODALITIES IN ABDOMINAL AND LOWER LIMB SURGERY - COMPARISON OF EFFICACY
}

\author{
Jasminka Peršec ${ }^{1,2}$, Monika Šerić ${ }^{1}$ \\ ${ }^{1}$ Clinic for Anesthesiology, Reanimatology and Intensive Care Medicine, Clinical Hospital Dubrava; \\ ${ }^{2}$ School of Dental Medicine, University of Zagreb, Croatia
}

\begin{abstract}
SUMMARY - A significant component of all surgical procedures and postoperative treatment is pain management.Due to the physiological and psychological advantages of pain relief, it is one of the foremost indicators of quality of care. Today, there are various modalities of pain reduction, aimed to reduce patient discomfort andminimize side effects, which can be divided by therapeutic agents used (opioid or non-opioid), route of administration (intravenous, regional, oral, etc.) and modality (controlled by patients or "as needed"). Although opioids have proven to be very effective pain relief agents and are commonly used in postoperative analgesia, concerns about their side effects have spurred the development of modified, multimodal treatments that seek to minimize opioid use and associated drawbacks. Enhanced recovery protocols that emphasize sparing administration of opioids are growing in importance, andresulting in reduced length of hospital stay after abdominal and lower limb surgery. To further improve such protocols and optimize postoperative care for individual patient needs, it is imperative to fully assess the efficacy of available drugs and analgesia modalities.
\end{abstract}

Key words: Analgesia, Pain, Pain Management, Postoperative Care

\section{Introduction}

Abdominal and lower limb surgeries often result in severe pain, which in turn can cause rapid and shallow breathing, retention of secretions, resulting with atelectasis, and poor patient compliance. ${ }^{1}$ Justifiably, apart from the fear for the surgery outcome, patients are concerned mainly with postoperative pain. ${ }^{2}$ If treated inadequately, acute pain can have serious consequences for patient health mainlywith postoperative complications, prolonged recovery and increased length of hospital stay. ${ }^{3}$ Moreover, it can ultimately result in onset of chronic pain and associated negative social and psychological effects (dissatisfaction, anxiety, stress) that impact patient's quality of life. ${ }^{4,5}$

Corresponding to: Assist. Prof. Jasminka Peršec, MD PhD, Clinic for Anesthesiology, Reanimatology and Intensive Care Medicine, Clinical Hospital Dubrava, Av. Gojka Šuška 6, Zagreb, Croatia e-mail: jpersec@xnet.hr
Adequate postoperative pain control is an important part of postoperative care treatment. World Health Organization, as well as International Association for the Study of Pain, have emphasized its significance for patients' well-being, and determined pain relief to be a human right and the occurrence of pain as "fifth vital sign". ${ }^{6}$ Although recent advances have considerably increased our understanding of nociception mechanisms and underlying physiology of pain, application in clinical practice is not always straightforward. As a result, postoperative pain control continues to be a challenge for anesthesiologists. ${ }^{7,8} \mathrm{With}$ increasing focus on undertreatment of postoperative pain and its potential detrimental effects on patients' well-being, new approaches have been introduced that modify surgical stress responses, reduce length of hospital stay, improve patient outcomes and satisfaction. Important tools that were developed to this end are minimally invasive surgery and enhanced recovery protocols (ERAS), multimodal approaches that share 
common goals of effective pain relief while minimizing harmful side effects. ${ }^{9}$

\section{Pre-emptive (preventive) Analgesia}

Analgesia administered before the surgery may prevent or significantly reduce pain or postoperative analgesic requirements. However, onlya few studies clearly demonstrated this effect. Primary mode of action of pre-emptive analgesia is the reduction of nociceptor activation by inhibition of receptor activation, and modulation of pain neurotransmitters activity. Multiple pharmacological agents are used, which can be administered locally via wound infiltration, into epidural space, or systemically prior to surgical incision. ${ }^{9}$ A meta-analysis of randomized trials of Ong $\mathrm{CK}$ et al. showed that pre-emptive epidural analgesia was more effective in reducing pain scores compared to local anesthetic wound infiltration and nonsteroidal anti-inflammatory administration, although both reduced analgesic consumption. ${ }^{10}$ Furthermore, studies showed no benefit in pre-emptive local anesthetic infiltration of laparoscopic port incision sites in terms of managing postoperative visceral pain. ${ }^{11,12}$ Overall, some short-term benefits may be observed with preemptive analgesia, especially in ambulatory surgery patients.

\section{Opioid Analgesia}

Due to their superior analgetic properties, opioids are still golden standard of postoperative pain therapy, with morphine being the first choice and most widely used for intravenous administration. Other than intravenous, opioids can be administered via oral, intramuscular, transdermal,spinal, epidural and rectal route.All opioids can cause respiratory depression, and increase the risk of hypoxia and respiratory arrest. ${ }^{13}$ Therefore, continuous monitoring of respiration and oxygen saturation is essential in postoperative care of patients on opioid therapy. Other side effects include vomiting, nausea, pruritus, and reduced bowel motility, which can lead to constipation and ileus. ${ }^{14,15}$ An important consideration for opioid use is their propensity to cause dependence and addiction, especially with longterm regimens. Addressing this issue, enhanced recovery protocols aim to reduce over-reliance on opioid analgesia, particularly in colorectal surgery, promoting other non-opioid medicaments and methods for postoperative pain treatment. ${ }^{16,17}$

\section{Intravenous Patient-Controlled Analgesia}

Patient-controlled analgesia (PCA) is a therapeutic modality which offers patient more autonomy and control over the amount and schedule of analgesic agent used. It requires special equipment (PCA pump) that allows administration of morphine, hydromorphone, and fentanyl. ${ }^{9}$ Randomized controlled trials demonstrated patient preference for IV PCA over intramuscular administered opioids, as they provide better pain control without increase in side effects. ${ }^{18}$ This was confirmed by a Cochrane Review that reported increased patients satisfaction scores when using IV PCA since it had stronger analgesic effect than conventional IV opioid therapy based on regular schedule of administration. No increase was found in the opioid consumption, pain scores, length of hospital stay, and incidence of opioid-related side effects. Thus, confirmingthat PCA is a suitable alternative to conventional analgesia inpostoperative pain management. ${ }^{19}$

\section{Epidural Analgesia}

Neuraxial regional analgetic blocks (epidural, spinal) are widely used in pelvic and abdominal surgery. Literature proved that they can reduce postoperative mortality and other serious complications. It is not yet clear whether these effects are thedirect benefits of neuraxial blockade alone or result of general anesthesia avoidance. ${ }^{20}$

Cochrane reviewed randomized controlled trials comparing IV PCA and continuous epidural analgesia (CEA), concluding that CEA was superior in pain reduction during first 72 hours after abdominal surgery. ${ }^{21}$ However, higher incidence of opioid-related pruritus was observed in patients with CEA. A meta-analysis by Block et al. reviewed the efficacy of postoperative epidural analgesia and parenteral opioids, concluding that epidural analgesia, regardless of analgesic agent used, catheter placement location or type and time of pain assessment, provided better postoperative analgesia. ${ }^{22}$ Another meta-analysis of Marret E et al. compared the same modes of opioid delivery in colorectal 
surgery and demonstrated significant reduction in postoperative pain intensity and ileus occurrence in CEA patient group, but also a higher number of adverse effects (hypotension, urinary retention). ${ }^{23} \mathrm{Co}^{-}$ administration of local anesthetic and opioid is possible witha patient-controlled epidural pump, thus lowering required dose of each agent and reducing the severity of side effects. ${ }^{24}$ Epidural catheter insertion is challenging, requires training andstrict adherence to guidelines regarding the coagulation status of the patient. Moreover, inadequate analgesia is observed in $27 \%$ patients with lumbar and $32 \%$ with thoracic epidural insertion, even when catheter is properly placed. ${ }^{25}$ Hypotension can occur in patients with functioning CEA, which requires additional intravenous fluids. ${ }^{26}$

\section{Spinal Analgesia}

A recent study on175 colorectal surgery patients of Virlos I et al. found that a singledose of intrathecal opioid followed by IV PCA provided better pain control compared to CEA and comparable results in return of gut function and incidence of postoperative nausea and vomiting. Additionally, rehabilitation time and length of hospital stay was reduced in the intrathecal analgesia group. ${ }^{27}$ Another randomized controlled study in laparoscopic colorectal surgery patients of Levy BF et al. compared CEA, intrathecal analgesia, and IV PCA. They found prolonged nausea, return of bowel function, and number of total hospital stay days in the CEA group, although in the early postoperative period pain scores were higher in the PCA group. ${ }^{28}$ Study of Wongyingsinn $\mathrm{M}$ et al. confirmed this positive effect of intrathecal analgesia in laparoscopic colorectal surgery patients. ${ }^{29}$

\section{Non-opioid Analgesia}

Modalities which reduceopioid consumption are a very important part of postoperative analgesia. Nonsteroidal anti-inflammatory drugs (NSAIDS) are useful in treatment ofmild to moderate pain levels, by reducingthe amount of opioids needed, thus reducing their side effects. ${ }^{9}$ Their mechanism of action includes cyclooxygenase (COX) inhibition, subsequently blocking prostaglandin production and acting anti-inflammatory. Noteworthy, having in mind the increased risk of bleeding with these agents and recent evidence of cardiovascular risks, COX-1 inhibitors are preferred over selective COX-2 inhibitors. ${ }^{30,31}$ Ketorolac is an injectable nonsteroidal anti-inflammatory agent with analgesic properties, predominantly affecting COX-1. It can be used as an adjunct to other agents and as preemptive analgesia. ${ }^{31}$ Ketorolac is commonly prescribed in colorectal surgery postoperative protocols as it has considerable opioid-sparing effect, reducing opioid administration by 25 to $45 \%$, and concurrently decreasing risk of postoperative ileus. ${ }^{31-33}$

Paracetamol is widely used for acute pain treatment. Its analgetic efficacy is acknowledged by a number of randomized controlled trials. ${ }^{34}$ However, maximum daily dose (4 g) should not be exceeded for it has hepatotoxic potential. Although it can be used as a sole agent, studiesreported its increased efficacy when combined with other analgetics, primarily NSAIDs. ${ }^{35}$ Paracetamol also has opioid-sparing effect, but unlike NSAIDs, it does not interfere with platelet function and can be used in patients with asthma or peptic ulcer. ${ }^{36}$

\section{Peripheral Nerve Blocks}

The transversus abdominis plane (TAP) block produces anesthesia of the abdominal wall. ${ }^{37}$ Variations include ultrasound-guided before operation and surgeon-administered transversus abdominis plane blocks at the time of abdominal closure. ${ }^{38}$ It is thought that this modality has a lower risk of complications and greater patient compliance than epidural analgesia. ${ }^{9}$ The main limitation of such blocks remains the duration of action, even of long-acting local anesthetics, which restricts their analgesic efficacy to around $24 \mathrm{~h}$ without catheter placement. ${ }^{39}$ Jakobsson et al. showed that TAP block patients compared to noTAP patients or saline placebo had significantly less postoperative morphine requirement at 24 and 48 hours. ${ }^{40}$ In ERAS protocol for laparoscopic colorectal surgery, TAP plus intravenous paracetamol results in earlier peristaltic recovery and hospital discharge compared to morphine PCA. ${ }^{17}$ A study of Brady RR et al.comparing TAP plus PCA with subcutaneous local infiltration plus PCA in open right hemicolectomies andshowed that TAP patients had reduced PCA morphine use during 24 hours and were less sedated. ${ }^{41}$ Conaghan et al.found decreased IV opioid use in laparoscopic colorectal resections with TAPand PCA combination 
compared to PCA alone. ${ }^{42}$ However, it can be concluded from several heterogeneous studies that TAP block efficacy depends on the operator variability and skill. ${ }^{9}$ Still, future studies will be needed to determine the role of TAP block and its efficacyto other modalities of pain management.

3 in 1 block is a peripheral nerve block, where femoral nerve $(\mathrm{FN})$, lateral cutaneous nerve (LFCN) and obturator nerve $(\mathrm{OBN})$ are blocked in a single injection. It is given postoperatively with the obvious advantage of maximizing the duration of sensory analgesia. It is an effective method of postoperative analgesia in lower limb surgery. ${ }^{2,43}$ Depending on the surgical procedure, femoral3-in-1 nerve block may cover only a part of the knee joint. The knee joint is innervated with the femoral, obturator, and sciatic nerve (SCN). With this block, parts of the knee innervated by the sciatic nerve will not be covered. The hip joint is primarily innervated by the femoral, obturator, and lateral femoral cutaneous nerve, with a small contribution from the sciatic nerve. Marhofer P et al. found that $20 \mathrm{ml}$ of $0.75 \%$ ropivacaine and $0.5 \%$ bupivacaine result in similar sensory onset times and quality of the block. ${ }^{44} \mathrm{Ad}-$ ditional analgesia with intravenous opioids should be sufficientfor small sciatic contribution. A recent study compared this block with intravenous Tramadol for postoperative analgesia and found that it provided better postoperative analgesia with greater hemodynamic stability, concluding that 3 in 1 block can be an alternative to IV Tramadol in patients with opioid complications. ${ }^{43}$

Lumbar plexus block (LPB) produces anesthesia of the ipsilateral lumbar plexus, the femoral nerve, lateral femoral cutaneous and the obturator nerve. It is used as a sole anesthesia technique or in combination with a sciatic nerve block for anesthesia and analgesia in patients undergoing hip and lower limb surgery. It is also referred to as psoas compartment block (PCB) or posterior lumbar plexus block (PLB). The term PCB was originally coined by Chayen and colleagues. They foundthat branches of the lumbar plexus and parts of the sacral plexus were located close at the L4 vertebra level, in the space between the psoas major muscle and quadratus lumborum muscles. Nye ZB et al. found that continuous posterior lumbar plexus block is a suitable method even for ambulatory hip arthroscopy. ${ }^{46}$ Sciatic nerve block provides postoperative analgesia for knee surgery, below knee surgery and ankle surgery. Single shot sciatic nerve block with posterior approach (Labat) provides effective postoperative analgesia in majority of the patients for up to 18 hours when combined with spinal anesthesia intraoperatively. ${ }^{47}$

\section{Local Infiltration}

Many operations can be performed inIV sedation combined with local anesthetic wound infiltration. ${ }^{48}$ This modality is an important part of multimodal postoperative pain treatment inERAS protocol for abdominal surgery patients. A limitation of the commonly used local anesthetics (lidocaine and bupivacaine) is the short duration of their action. Liposomal bupivacaine is a new formulation that can provide longer analgesia for up to 72 hours and is approved for postsurgical wound analgesia.However, literature data on experience with its use is lacking. ${ }^{49}$ One study reported successful management of loop ileostomyclosure using multimodality postoperative pain management (liposomal bupivacaine, paracetamol, andibuprofen). ${ }^{9}$ Ventham NT et al. investigated meta-analysis of randomized clinical trials comparing continuous wound infiltration and epidural analgesia in abdominal surgery. Postoperative pain scores among patient groups were comparable. ${ }^{39}$ It seems that the potential of local infiltration lies within multimodality approach.

\section{Conclusion}

Effective post-operative pain management is mandatory for every patient, as it canpositively affect postoperative recovery and clinical outcomes.It encompasses adequate intraoperative analgesia, early postoperative pain assessment and sufficient postoperative analgesia during postoperative period. There is no single optimal modality for postoperative pain relief and many considerations should be taken into account when tailoring analgesia regimen for each individual patient. In ambulatory surgery, pre-emptive analgesia with NSAIDs or paracetamol and regional blocks are methods of choice. For abdominal surgery patients PCA could be appropriate. Adding NSAIDs to opioids will result in lower opioiduse and improve analgesia quality with minimal side effects. For patients undergoing procedures requiring extensive incisions, postoperative epidural or intrathecal analgesia is rec- 
ommended. Multimodal pain management therapy should be used, whenever possible. In this approach, regional blocks in abdominal and lower limb surgery play an important role and enhance recovery after operation. As Rawal stated, the actual solution to the problem of inadequacy of post-operative pain management does not lie in the acquisition of expensive medication or development and use of new techniques, but rather in the optimal utilization of already available drugs, techniques, facilities and establishment of formal pain management services. ${ }^{50}$

\section{Acknowledgment}

Authors state no conflict of interest.

\section{References}

1. Ahmed A, Latif N, Khan R. Post-operative analgesia for major abdominal surgery and its effectiveness in a tertiary care hospital. J Anaesthesiol Clin Pharmacol. 2013;29(4):472-7.

2. Mukiri SRKR. Int Surg J. 2015 Nov;2(4):475-9.

3. Kehlet H, Holte K. Effect of postoperative analgesia on surgical outcome. Br J Anaesth. 2001;87(1):62-72.

4. White PF, Kehlet H. Improving postoperative pain management: What are the unresolved issues? Anesthesiology 2010; 112:220-5.

5. Kehlet H, Jensen T S, Woolf C J. Persistent postsurgical pain: risk factors and prevention. Lancet. 2006;367(9522):1618-25.

6. Brennan F, Carr D B, Cousins M. Pain management: a fundamental human right. Anesth Analg. 2007;105(1):205-21.

7. Wardhan R, Chelly J. Recent advances in acute pain management: understanding the mechanisms of acute pain, the prescription of opioids, and the role of multimodal pain therapy. F1000Res. 2017;6:2065. Published 2017 Nov 29.

doi:10.12688/f1000research.12286.1

8. Shapiro A , Zohar E , Hoppenstein D, Ifrach N , Jedeikin R , Fredman B . A comparison of three techniques for acute postoperative pain control following major abdominal surgery. $\mathrm{J}$ Clin Anesth. 2003 Aug;15(5):345-50.

9. Garimella V, Cellini C. Postoperative pain control. Clin Colon Rectal Surg. 2013;26(3):191-6.

10. Ong CK, Lirk P, Seymour RA, Jenkins BJ. The efficacy of preemptive analgesia for acute postoperative pain management: a meta-analysis. Anesth Analg 2005;100(3):757-73.

11. Ghezzi F, Cromi A, Bergamini V, et al. Preemptive port site local anesthesia in gynecologic laparoscopy: a randomized, controlled trial. J Minim Invasive Gynecol 2005;12(3):210-215.

12. Leung CC, Chan YM, Ngai SW, Ng KF, Tsui SL. Effect of pre-incision skin infiltration on post-hysterectomy pain - a double-blind randomized controlled trial. Anaesth Intensive Care 2000;28(5):510-6.

13. Luo J, Min S. Postoperative pain management in the postanesthesia care unit: an update. J Pain Res. 2017;10:2687-98.

14. Barletta JF, Asgeirsson T, Senagore AJ. Influence of intravenous opioid dose on postoperative ileus. Ann Pharmacother 2011;45(7-8):916-23.

15. Goettsch WG, Sukel MP, van der Peet DL, van Riemsdijk MM, Herings RM. In-hospital use of opioids increases rate of coded postoperative paralytic ileus. Pharmacoepidemiol Drug Saf 2007; 16(6):668-74.

16. Levy BF, Tilney HS, Dowson HM, Rockall TA. A systematic review of postoperative analgesia following laparoscopic colorectal surgery. Colorectal Dis 2010;12(1):5-15.

17. Zafar N, Davies R, Greenslade GL, Dixon AR. The evolution of analgesia in an 'accelerated' recovery programme for resectional laparoscopic colorectal surgery with anastomosis. Colorectal Dis 2010;12(2):119-24.

18. Ballantyne JC, Carr DB, Chalmers TC, Dear KB, Angelillo IF, Mosteller F. Postoperative patient-controlled analgesia: metaanalyses of initial randomized control trials. J Clin Anesth 1993;5(3):182-93.

19. Hudcova J, McNicol E, Quah C, Lau J, Carr DB. Patient controlled opioid analgesia versus conventional opioid analgesia for postoperative pain. Cochrane Database Syst Rev 2006;(4): CD003348.

20. Rodgers A, Walker N, Schug S, McKee A, Kehlet H, van Zundert A, et al. Reduction of postoperative mortality and morbidity with epidural or spinal anaesthesia: results from overview of randomised trials. BMJ 2000;321:1493.

21. Werawatganon T, Charuluxanun S. Patient controlled intravenous opioid analgesia versus continuous epidural analgesia for pain after intra-abdominal surgery. Cochrane Database Syst Rev 2005; (1):CD004088.

22. Block BM, Liu SS, Rowlingson AJ, Cowan AR, Cowan, Jr JA, Wu CL. Efficacy of Postoperative Epidural Analgesia: A Meta-analysis. JAMA. 2003;290(18):2455-63. doi:10.1001/ jama.290.18.2455

23. Marret E, Remy C, Bonnet F, Postoperative Pain Forum G; Postoperative Pain Forum Group. Meta-analysis of epidural analgesia versus parenteral opioid analgesia after colorectal surgery. Br J Surg 2007;94(6):665-73.

24. Mann C, Pouzeratte Y, Boccara G, et al. Comparison of intravenous or epidural patient-controlled analgesia in the elderly after major abdominal surgery. Anesthesiology 2000;92(2): 433-41.

25. Hermanides J, Hollmann MW, Stevens MF, Lirk P. Failed epidural: causes and management. Br J Anaesth 2012;109(2): 144-54.

26. Allen S, DeRoche A, Adams L, et al. Effect of epidural compared to patient-controlled intravenous analgesia on outcomes for patients undergoing liver resection for neoplastic disease. J Surg Oncol. 2017;115(4):402-6. 
27. Virlos I, Clements D, Beynon J, Ratnalikar V, Khot U. Shortterm outcomes with intrathecal versus epidural analgesia in laparoscopic colorectal surgery. Br J Surg 2010;97(9):1401-6.

28. Levy BF, Scott MJ, Fawcett W, Fry C, Rockall TA. Randomized clinical trial of epidural, spinal or patient-controlled analgesia for patients undergoing laparoscopic colorectal surgery. Br J Surg 2011;98(8):1068-78.

29. Wongyingsinn M, Baldini G, Stein B, Charlebois P, Liberman S, Carli F. Spinal analgesia for laparoscopic colonic resection using an enhanced recovery after surgery programme: better analgesia, but no benefits on postoperative recovery: a randomized controlled trial. Br J Anaesth 2012;108(5):850-6.

30. Dajani EZ, Islam K. Cardiovascular and gastrointestinal toxicity of selective cyclo-oxygenase-2 inhibitors in man. J Physiol Pharmacol 2008;59(Suppl 2):117-33.

31. De Oliveira GS Jr, Agarwal D, Benzon HT. Perioperative single dose ketorolac to prevent postoperative pain: a meta-analysis of randomized trials. Anesth Analg 2012;114(2):424-33.

32. Chen JY, Wu GJ, Mok MS, et al. Effect of adding ketorolac to intravenous morphine patient-controlled analgesia on bowel function in colorectal surgery patients - a prospective, randomized, double-blind study. Acta Anaesthesiol Scand 2005;49 (4):546-51.

33. Chen JY, Ko TL, Wen YR, et al. Opioid-sparing effects of ketorolac and its correlation with the recovery of postoperative bowel function in colorectal surgery patients: a prospective randomized double-blinded study. Clin J Pain 2009;25(6): 485-9.

34. Toms L, McQuay HJ, Derry S, Moore RA. Single dose oral paracetamol (acetaminophen) for postoperative pain in adults. Cochrane Database Syst Rev 2008;(4):CD004602.

35. Ong CK, Seymour RA, Lirk P, Merry AF. Combining paracetamol (acetaminophen) with nonsteroidal anti-inflammatory drugs: a qualitative systematic review of analgesic efficacy for acute post-operative pain. Anesth Analg 2010;110 (4):1170-9.

36. Maund E, McDaid C, Rice S, Wright K, Jenkins B, Woolacott N. Paracetamol and selective and non-selective non-steroidal anti-inflammatory drugs for the reduction in morphine-related side-effects after major surgery: a systematic review. Br J Anaesth 2011;106(3):292-7.

37. Charlton S, Cyna AM, Middleton P, Griffiths JD. Perioperative transversus abdominis plane (TAP) blocks for analgesia after abdominal surgery. Cochrane Database Syst Rev 2010; (12):CD007705
38. Brady RR, Ventham NT, Roberts DM, Graham C, Daniel T. Open transversus abdominis plane block and analgesic requirements in patients following right hemicolectomy. Ann R Coll Surg Engl. 2012;94(5):327-30.

39. Ventham NT, Hughes M, O’Neill S, Johns N, Brady RR, Wigmore SJ. Systematic review and meta-analysis of continuous local anaesthetic wound infiltration versus epidural analgesia for postoperative pain following abdominal surgery. Br J Surg. 2013 Sep;100(10):1280-9.

40. Jakobsson J, Wickerts L, Forsberg S, Ledin G. Transversus abdominal plane (TAP) block for postoperative pain management: a review. F1000Res. 2015;4:F1000 Faculty Rev-1359. Published 2015 Nov 26. doi:10.12688/f1000research.7015.1

41. Brady RR, Ventham NT, Roberts DM, Graham C, Daniel T. Open transversus abdominis plane block and analgesic requirements in patients following right hemicolectomy. Ann R Coll Surg Engl 2012;94(5):327-30.

42. Conaghan P, Maxwell-Armstrong C, Bedforth N, et al. Efficacy of transversus abdominis plane blocks in laparoscopic colorectal resections. Surg Endosc 2010;24(10):2480-4.

43. Bengali R. 3 in 1 block for postoperative analgesia in lower limb surgery. Indian J Appl Res 2018;8(5):69-70.

44. Marhofer P, Oismuller C, Faryniak B, Sitzwohl C, Mayer N, Kapral S. Three-in-one blocks with ropivacaine: Evaluation of sensory onset time and quality of sensory block. Anesth Analg 2000;90:125-8.

45. Hartmann FV, Novaes MR, de Carvalho MR. Femoral nerveblock versus intravenous fentanyl in adult patients with hip fractures - a systematic review. Braz J Anesthesiol. 2017 Jan Feb;67(1):67-71. doi: 10.1016/j.bjane.2015.08.017

46. Nye ZB, Horn JL, Crittenden W, Abrahams MS, Aziz MF. Ambulatory continuous posterior lumbar plexus blocks following hip arthroscopy: a review of 213 cases. J Clin Anesth. 2013 Jun;25(4):268-74. doi: 10.1016/j.jclinane.2012.11.013.

47. Sinha SA, Mutha SC, Phalgune DS. Efficacy of Sciatic Nerve Block for Pain Management in below Knee Orthopaedic Surgery. J Clin Diagn Res. 2016 Sep;10(9):UC17-UC20.

48. Scott NB. Wound infiltration for surgery. Anaesthesia 2010;65 (Suppl 1):67-75.

49. Cohen SM. Extended pain relief trial utilizing infiltration of Exparel $\left({ }^{\circledR}\right)$, a long-acting multivesicular liposome formulation of bupivacaine: a Phase IV health economic trial in adult patients undergoing open colectomy. J Pain Res 2012;5:567-572.

50. Rawal N. Acute pain services revisited: Good from far, far from good? Reg Anesth Pain Med 2002;27:117-21. 


\title{
Sažetak \\ MODALITETI REGIONALNE ANALGEZIJE \\ U ABDOMINALNOJ KIRURGIJI I KIRURGIJI DONJIH EKSTREMITETA - USPOREDBA UČINKOVITOSTI
}

\begin{abstract}
J. Peršec i M. Šerić
Zbrinjavanje boli predstavlja značajan dio svakog kirurškog zbrinjavanja i postoperativnog liječenja. Zbog tjelesnih i psiholoških benefita, učinkovita analgezija danas se smatra jednim od najvažnijih pokazatelja kvalitete zdravstvene skrbi. Postoji više modaliteta liječenja boli, s ciljem umanjivanja nelagode za pacijenta i minimiziranja neželjenih učinaka do kojih pritom može doći. Modalitete analgezije razlikujemo prema vrsti korištenog agensa (opioidni ili neopioidni), prema načinu primjene lijeka (intravenski, regionalno, peroralno, itd.) te jesu li kontrolirani od strane pacijenta ili se uzimaju po potrebi. Iako su opioidi dokazano vrlo učinkoviti, i najčešće korišteni lijekovi u terapiji poslijeoperacijske boli, ne jenjava zabrinutost zbog njihovih nuspojava. Posljedično, došlo je do razvoja modificiranih, multimodalnih načina liječenja, koji nastoje umanjiti ili izbjeći upotrebu opioida. Isto naglašavaju aktualne smjernice za ubrzani oporavak nakon operacije, koje se sve šire primjenjuju jer dokazano ubrzavaju oporavak i skraćuju ukupni boravak pacijenta u bolnici nakon operacija abdomena i donjih ekstremiteta. Neophodno je dobro procijeniti učinkovitost dostupnih lijekova i analgetskih modaliteta kako bi se protokoli i dalje unaprijeđivali, a postoperacijska skrb optimizirala i individualizirala.
\end{abstract}

Ključne riječi: Analgezija, Bol, Zbrinjavanje boli, Postoperacijska skrb 